\title{
Blanchot e Hölderlin: Impulso ao Abismo e INFIDELIDADE DIVINA
}

\author{
Blanchot and Hölderlin: impulse towards abyss and \\ divine infidelity
}

Jorge Luiz Viesenteiner*

Ao longo de seus escritos, Blanchot fez freqüentes referências a Hölderlin. No geral, dois textos são sumariamente importantes no tocante à trajetória do poeta trágico interpretado por um crítico literário maldito. Trata-se de um texto em $A$ parte do fogo intitulado "A palavra 'sagrada' de Hölderlin" e outro nomeado como "O itinerário de Hölderlin" publicado em o espaço literário. Ambos os textos, respectivamente, tratam da juventude e da maturidade de Hölderlin, quer dizer, tanto da fase do Hypérion e Empédocles quanto do período das Observações sobre Édipo e Observações sobre Antigona. Claro que outras alusões a Hölderlin também são registradas, mas de modo mais sistemático estes textos são os que mais bem exploram a dimensão trágica do poeta.

Neste sentido, este texto vai tentar analisar, por um lado, os textos de juventude de Hölderlin em que o poeta anseia por um sentimento de unidade ou conciliação entre natureza e arte, e que deve se realizar no personagem trágico - realização conciliatória que ocorre de forma trágica numa espécie de impulso ao abismo - e, por outro lado, a noção de infidelidade divina que aparece na maturidade de Hölderlin a propósito da apresentação do trágico, quer dizer, uma espécie de impulso que resta ao homem apenas a terra, depois que o poeta experimenta a "noite do afastamen- 
to dos deuses". ${ }^{1}$ Essas anotações seguem o curso das reflexões refinadíssimas que Blanchot faz sobre o poeta alemão, acrescentando outras observações de amplo alcance tanto teórico quanto literário.

HÖLDERLIN E O IMPULSO AO ABISMO

O jovem Hölderlin ainda é atravessado por um forte sentimento de unidade com a natureza. Sentimento de abandono inexorável de todos os limites em proveito de uma existência no seio da Natureza num total esquecimento de si. Desejo presente no Hypérion, por exemplo, cujo personagem se encarregaria, segundo Diotima, de educar o povo para este sentimento: "Serás o educador de nosso povo, serás um grande homem, espero. (...) Haverá de ser uma única beleza. Humanidade e natureza haverão de reunirse em uma divindade tudo abrangente." ${ }^{2}$ A bem da verdade, o desejo de unidade é propriamente um impulso à morte, anseio que foi igualmente celebrado por Hölderlin num texto inacabado sobre Empédocles. Profundo conhecedor da natureza, Empédocles é uma espécie de redentor da multidão que, mesmo tendo sido condenado ao exílio e depois absolvido, assume a opção trágica de um destino que culmina numa atração irresistível: o que chamamos aqui de impulso ao abismo, trajetória percorrida pelo filósofo que o faz criar um vínculo estreito com os deuses. A relação trágica entre natureza e arte é perfeitamente compreendida em Hölderlin como relação de estreita necessidade e dependência entre o homem e os deuses. Assim, tanto as oposições natureza/arte quanto homem/deuses devem ser resolvidas numa conciliação que ocorre através de sua celebração na tragédia, mas que Blanchot analisa como ocorrendo também através da existência poética e as profundas contradições que acompanham a poesia.

Obcecado pela idéia de Totalidade, Hölderlin registrou numa carta a Schiller de 4 de setembro de 1795 a via pela qual se garante, esteticamente, o sentimento de plena unidade e abandono: trata-se da noção de intuição intelectual.

Objetivo desenvolver a idéia de um processo sem fim da filosofia; pretendo mostrar como a exigência iniludível que deve se empregar a todo sistema, a união do sujeito e do objeto no Absolu-

SZONDI, Peter. Ensaio sobre o trágico. Tradução: Pedro Süssekind. Rio de Janeiro: Jorge Zahar, 2004. p. 36.

${ }_{2}$ HÖLDERLIN, Friedrich. Hypérion. Tradução: Márcia Sá Cavalcante Schuback. Petrópolis: Vozes, 1993. p. 107. 
to - eu ou como quiser chamá-lo - é, sem dúvida, possível esteticamente na intuição intelectual, teoricamente em troca só é possível mediante uma aproximação sem fim, tal qual a aproximação do quadrado ao círculo, e como, para realizar um sistema do pensamento, é necessária uma imortalidade tanto como para um sistema da ação. ${ }^{3}$

Obtida esteticamente pela tragédia, a intuição intelectual é o meio que Hölderlin indica para o impulso de união com o Absoluto. $O$ conflito que ocorre entre natureza e arte é solucionado no homem, como personagem trágico, que só atinge sua perfeita identidade se ele aceita a função criadora da aniquilação, tal como o faz Empédocles. ${ }^{4} \mathrm{O}$ impulso trágico ao abismo é na verdade anseio obstinado por vida em toda sua plenitude, vida como abandono de si mesmo e rompimento com todo limite que o personagem trágico deve levar às últimas conseqüências. No extremo limite em que o homem é seduzido pelo eco do abismo ele está apto a ser um filho do tempo, quer dizer, assumir em si a conciliação entre natureza e arte: "Um homem em que aqueles opostos se unem tão intimamente que nele se tornam Um...". ${ }^{5}$ O perecimento pela sedução do abismo é aceitação do que há de produtivo na aniquilação.

Blanchot fica fascinado com este impulso trágico de identificação com a Totalidade que ele encontra no jovem Hölderlin, mas se pergunta precisamente em que consiste esta existência, caracterizada por ele como existência poética.

A poesia é o veículo apropriado para celebrar a natureza como "todo-presente" e, de fato, Hölderlin conseguiu essa celebração através do paradoxo segundo o qual, o impulso artístico é "propriamente um serviço que os homens prestam à natureza". ${ }^{6}$ Nessa celebração artística que homenageia a natureza, Blanchot se preocupa com o personagem trágico por excelência: o poeta e a possibilidade da existência poética, que para ele, é aquele que assume a função da aniquilação ao nomear a própria natureza por meio da poesia. Sem a existência poética "a natureza perderia sua essência de todo-presente e o mundo seria apenas o Universo. Ora, é o que aconteceria se no mundo faltasse o poema". ${ }^{7}$ O poeta, pois, é justamente aquele arrebatado por um impulso artístico que presta serviço à natureza.

3 HÖLDERLIN, Friedrich. In: GÁBAS, Rául. El todo-uno del idealismo alemán em la poesia de Hölderlin. In: Enrahonar, 32/33, p. 43-65, 2001. p. 51. As traduções são de nossa autoria, salvo indicação contrária.

Cf. SZONDI, Peter. op.cit., p. 34.

HÖLDERLIN, Friedrich. In: SZONDI, Peter. op.cit., p. 34.

Ibid., p. 33. Referência da "Carta de Homburg" de 4 de junho de 1794 a seu irmão.

BLANCHOT, Maurice. A parte do fogo. Tradução: Ana Maria Scherer. Rio de Janeiro:

Rocco, 1997. p. 117. 
Ao nomeá-la poeticamente, além de prestar um serviço à natureza, o poeta assume também o impulso ao abismo, o extermínio da própria morada para lançar-se novamente no nomadismo, porque se a morte foi a tentação de Empédocles, "para o poeta, a morte é o poema", ${ }^{8}$ visto ser ele o momento extremo da oposição cujo instante coincide com o aparecimento do poema, mas, ao mesmo tempo, com o desaparecimento do poeta. Mas vejamos como Blanchot analisa essa existência também paradoxal do poeta.

Blanchot identifica o mesmo ímpeto por unidade nos poemas de Hölderlin. A poesia se relaciona com a natureza compreendida como "todopresença", mais ou menos como Empédocles a caracterizava, isto é, "totalidade sem limites que significa ao mesmo tempo uma totalidade que não limita nem o real nem o irreal e um Todo em que, portanto, se integra e se compreende essa liberdade de não ser limitada por nada". ${ }^{9}$ Engajados um ao outro, Todo e poesia são os elementos que servem ao poeta a fim mediar a celebração da natureza. Nisso está a relação de necessidade entre natureza e poesia que comentamos anteriormente: sem o poema, a natureza deixa de ser todo-presença e, neste caso, o poeta é aquele prestador de serviço.

Se Hölderlin falava de um paradoxo no impulso artístico do homem em relação à natureza, Blanchot também vislumbra um paradoxo no que se refere à existência poética. Ora, se a natureza só existe graças ao canto poético e ao poeta como mediador, o interessante é que também o poeta, aquele que celebra a natureza pelo canto, "só pode vir ao mundo se o mundo é o Universo conciliado e pacificado, capaz de envolvê-lo, de abraçá-lo, de 'educá-lo' poeticamente, isto é, um universo onde o poeta, já presente, realiza sua obra". ${ }^{10}$ Segundo Blanchot, o conflito entre natureza e arte, neste caso, se dá através do poeta como aquele que deve resolver as oposições, mas que, ao mesmo tempo, vive ele mesmo uma contradição, pois se a natureza é dependente dele para ser homenageada, também o poeta já sempre necessita do Todo-presente que o "abraça" para celebrar a natureza. Segundo Blanchot, a solução desse paradoxo se dá no fato de que a existência do poeta como mediador vai ser compreendida como experimentação de uma vida na impossibilidade, ou seja, o poeta deve viver precisamente o mais extremo desse paradoxo, a própria impossibilidade de existência, para poder prestar serviço à natureza. A experimentação da impossibilidade da existência é justamente o eco do abismo, o pressentimento trágico que o poeta deve assumir e se lançar, experimentação de abandono de si em proveito do poema.

A existência poética nunca se dá quando o poeta é ele mesmo. É necessário ser sempre outro quando já se conseguiu ser alguma coisa, 
movimento que deve ser continuamente intensificado até que ele reúna em si as condições da conciliação dos opostos. Existir como outro, como impossibilidade de existir, é assumir o próprio nomadismo, transfigurar e dissimular ininterruptamente parodiando o próprio momento para assegurar o devir, garantir a impossibilidade mesma. Trata-se de um pressentir, quer dizer, "o poeta deve existir como pressentimento dele mesmo, como futuro de sua existência"; semelhante ao próprio contexto histórico vivido por Hölderlin, que é o tempo do desamparo, um "presente nulo, fechado nessa nulidade pela dupla ausência dos deuses, já desaparecidos ou ainda não aparecidos". A experiência da impossibilidade se dá quando o poeta se torna por vir, um "ainda não", como alguém que ainda não é, mas que transfigura para o que será mais tarde, "pois é essa existência sempre por vir do poeta que torna possível todo o futuro e mantém firmemente a história na perspectiva de um 'amanhã' mais rico de sentido, para o qual é preciso se esforçar no vazio do dia vivido." ${ }^{11}$ o poeta existe na impossibilidade quando vive como pressentimento de si mesmo, abandono inexorável na torrente trágica do devir. Não tem morada nem fixação e, portanto, nomadismo em que só resta ao poeta a existência sempre extemporânea, nunca localizada, eternamente por vir.

Ora, existência extemporânea é a característica do poema. $\mathrm{O}$ "agora" do poema nunca se dá numa exigência histórica, mas como obra ainda a se realizar, obra ou livro por vir, "existência ainda não acontecida" mas que é pressentimento de existência. O poema, tal como os deuses, deve ser sempre maior que seu tempo e sua região. Nas palavras de Hölderlin: “... Quando vem a hora, /Como o mestre, ele sai do ateliê, /E o traje que então veste /É traje de festa, /Em sinal da obra/ Que lhe falta ainda realizar". ${ }^{12} \mathrm{O}$ poema como por vir é obra informe, inacabada e sempre em vias de se fazer; ${ }^{13}$ uma temporalidade que não está inscrita na história, mas antes, é o outro da própria temporalidade ou seu fora, uma região fronteiriça que seduz o poeta e o faz sucumbir.

O poema é, portanto, existência como pressentimento e por vir, mas que existe antes mesmo do poeta. ${ }^{14}$ Este, por sua vez, precisa existir na temporalidade do poema. Assim, tanto o poeta quanto o poema vivem numa estreita dependência cuja sintonia precisa se realizar na experimentação da impossibilidade de existir, ou seja, no devir que jamais se fixa e na vertigem de se estar sob a constante sedução do abismo. O segundo sentido de existir na impossibilidade é precisamente a sintonia de dependência entre poema e

\footnotetext{
BLANCHOT, Maurice. op.cit., p. 118.

HÖLDERLIN, Friedrich. "Como um dia de festa". In: BLANCHOT, op.cit., p. 113.

Cf. DELEUZE, Gilles. "A literatura e a vida". In: Crítica e clínica. Tradução: Peter P.
} Pelbart. São Paulo: Ed. 34, 1997. p. 11.

14 BLANCHOT, Maurice. op.cit., p. 119. 
poeta, num curso de temporalidade que não se deixa captar pela história, pois se trata do outro do tempo.

Esse poder anterior do poema, que é capaz de ir para além dos homens e dos deuses, é propriamente o eco sedutor que emerge do abismo. Ao ter que existir na temporalidade do poema, no outro do tempo e no fluxo nômade do devir, o poeta é como que arrebatado por esta potência anterior. Exclusivamente pressentimento, o poeta respira a atmosfera de vertigem do abismo para celebrar esse abraço que o Todo-presente o oferece através da nomeação da natureza. Ao existir na impossibilidade, condição para que o poeta preste serviço à Totalidade, ele responde à exigência dessa potência anterior que Hölderlin chamou de "Sagrado": "E o que vivo, o Sagrado seja minha palavra". ${ }^{15}$ O Sagrado, ou antes, a palavra sagrada, é o "imediato", aquilo de que em nós se revela como o mais íntimo e que Blanchot comenta como sendo um imediato que jamais é comunicado, mas que, paradoxalmente, é precisamente o princípio de toda comunicação. Para além dos deuses e dos homens, o Sagrado é a potência que ecoa pelo vazio do abismo e que cabe ao poeta a função de celebrar o Todo-presente como resposta à pressão do Sagrado: "Nós te nomeamos, pressionados pelo Sagrado, nós te nomeamos /Natureza, tu nos...". ${ }^{16}$

Assim é que devemos entender o sentido do serviço prestado pelo poeta à natureza. Respondendo ao apelo exigente do Sagrado, o poeta se transforma em mediador entre palavra sagrada e natureza a fim de celebrála. A palavra "sagrada" de Hölderlin é sedução abismal; potência que faz com que a natureza seja Natureza somente através da resposta que o poeta dá ao sagrado, nomeando o Todo-presente e criando um vínculo de dependência entre homem e natureza. Szondi, a propósito da interpretação da tragédia por Hölderlin, também fala disso quando indica que uma das funções dos textos de juventude do poeta alemão é de "conferir ao homem uma posição que, embora o coloque como servo da natureza, mostre ao mesmo tempo que ela também depende dele".${ }^{17}$ No caso da tragédia, o herói é subjugado pelo poder da natureza e se torna insignificante; mas, uma vez que é aniquilado, o herói trágico celebra a natureza a fim de que ela apareça em sua mais superior manifestação. No caso do poema que é revelado pela resposta do poeta à exigência do sagrado, a natureza é cantada e passa a existir em toda sua manifestação. Blanchot arremata assim essa idéia: "poder resplandecente cujo jorro é a lei, princípio de aparecimento do que aparece, origem de todo o poder de comunicar, se isto é o Sagrado, compreendese que, 'pressentindo-o', o poeta já se coloque no centro da todo-presença e 
que a aproximação do Sagrado seja para ele a aproximação da existência". ${ }^{18}$

Assim, se o Todo-presente depende da mediação do poeta para existir e vice-versa, a única possibilidade de existência do poeta só pode se dar na impossibilidade, como mediador ou por vir, pois, existindo num "ainda não", pressente a sedução abismal da potência do Sagrado e o responde através do canto (poema) que se revela como celebração da Natureza. Portanto, o poeta canta a natureza porque existe num "ainda não", pondo-se como mediador que responde ao sagrado para fazer existir a natureza, mediação essa que é propriamente por vir, a única temporalidade em que experimenta o outro do tempo, a região fronteiriça habitada pelo poema.

O outro sentido do serviço que o homem presta à natureza é propriamente o poema como tal. Ele é palavra infinita que surge da finitude do poeta, que garante duração ao Todo-presente, impedindo-o que se perca numa totalidade sem limites, embora esta ilimitação seja realmente o que caracteriza a Natureza. O poema é linguagem finita e palavra duradoura em oposição à linguagem dos deuses que é porvir e mudança. A natureza precisa ser celebrada numa linguagem que permaneça, que possa ser vestígio: "Pois sempre o júbilo do Universo/ Tende a se afastar da Terra e a deixála/ Despojada, se o humano não a retém. Mas de uma palavra/ Fica o vestígio; que um homem pode entender" ${ }^{19}$ Celebrando a natureza, o poeta presta serviço a ela ao produzir o poema numa linguagem que permanece. Nisso os deuses são profundamente dependentes do humano: da palavra que dura e permanece:

Isto será o papel da palavra, cuja essência é ficar, mesmo vestígio, ser fundamento do que fica, estabelecer "entre o dia e a noite algo verdadeiro". A linguagem dos deuses é porvir e mudança ( $O$ arquipélago), mas a linguagem mortal é persistência, afirmação de uma duração que dura, unidade do tempo rasgada. É nisso que os Imortais necessitam dos mortais, necessitam da finitude: é ela que os estabelece no mundo e lhes dá o ser na consciência de ser. ${ }^{20}$

o poema, palavra sagrada que além de nomear também celebra a natureza, é capaz de fazer o infundado se tornar fundamento; palavra que mantém junto e impede que o Todo-presente se perca na totalidade do sem limite que o caracteriza. Em Patmos Hölderlin assim falou sobre o poema:

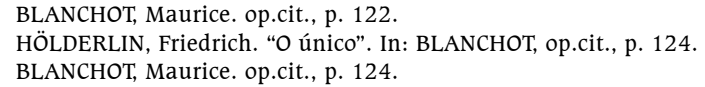


“... O Pai,/ Que reina sobre todas as coisas,/ Ama por excelência que cuidemos/ Da letra firme e que bem/ Significado seja o estável. A isso responde o canto alemão". ${ }^{21}$

O mais trágico da existência poética é que, tal como Empédocles que só consegue dar sentido à existência na total aniquilação de si, quer dizer, precisamente o momento em que o herói se torna "sem efeito" porque sucumbiu ao impulso sedutor do abismo, o poeta como mediador e celebrante da natureza precisa, inexoravelmente, perder-se a si mesmo também através do poema. A celebração do poema coincide, para o poeta, com a sentença trágica que recebe: “... Sua sentença/ É que sua própria casa/ Ele a destrua e ao que tenha de mais caro,/ E o trate como inimigo e a seu pai e filho,/ $\mathrm{E}$ os enterre sob os escombros". ${ }^{22}$

O poeta precisa destruir sua morada se quiser ser mediador que, neste caso, compreende-se como o lugar das mais extremas oposições. 0 trágico que o poeta reúne em si é justamente por assumir uma existência como "ainda não" e por vir, existir na impossibilidade que responde ao eco sagrado do abismo para cantar a natureza. $O$ conflito entre a exigência da palavra sagrada com a dependência que a natureza tem do poeta, inscreve nele a sentença trágica: existência que aceita a função criadora da aniquilação e que se completa por definitivo com seu dilaceramento. O poeta acaba por assumir o mesmo destino trágico de Empédocles, pois ambos são o lugar da "oposição extrema" que não admite qualquer esquiva, mas antes, existência que se reconhece como destinada ao impulso da sedução abismal a fim de conciliar em si a oposição entre exigência da palavra sagrada e natureza, quer dizer, "um homem em que aqueles opostos se unem tão intimamente que nele se tornam Um...". ${ }^{23}$

Para o poeta, a tentação sedutora do abismo é o poema. Ao fundar o infundado através da palavra que dura, ou ao fazer aparecer o poema que nomeia e faz existir o Todo-presente, o poeta aceita o fado do desaparecimento. Ao cantar a natureza pelo poema, as oposições extremas são conciliadas porque, por um lado, o poeta responde ao apelo exigente da palavra sagrada que ecoa sedutoramente do abismo e, por outro lado, fixa de maneira permanente a palavra que dá sentido à existência da Natureza, mas, paradoxalmente, precisa aceitar sua aniquilação para fazer aparecer o poema. Seu dilaceramento e destruição é função criadora, é celebração poética: 
Mas para Hölderlin, para o poeta, a morte é o poema. É na poesia que ele deve atingir o momento extremo da oposição, o momento em que ele é levado a desaparecer e, desaparecendo, a elevar ao máximo o sentido daquilo que só pode ser realizado nesse desaparecimento. Impossível, a reconciliação do Sagrado com a palavra exigiu da existência do poeta que ela se aproximasse ao máximo da inexistência. Foi então que ela própria, por um momento, apareceu como possível, quando, antes de submergir, consentiu em se afirmar no canto, vindo de um corpo já silencioso, pronunciado por uma voz morta..... ${ }^{24}$

A existência poética, enfim, é tão trágica e paradoxal quanto a compreensão da tragédia por Hölderlin. Tanto Empédocles quanto o poeta sucumbem à sedução do abismo a fim de conciliar as oposições que neles se transformam em Unidade. $O$ impulso à morte que dá sentido para Empédocles e concilia por completo as oposições entre arte e natureza, no caso do poeta, revela-se como impulso de sedução ao abismo que o faz sucumbir e desaparecer ao mesmo tempo em que o poema é revelado. Para o poeta, a poesia é tentação que culmina em sedução trágica. Neste ponto, o poeta não pode se esquivar, restando a ele apenas o impulso ao abismo.

HöLDERLIN E A INFIDELIDADE DIVINA

Os textos de juventude expressam o que Hölderlin falou posteriormente a respeito dos Hespérides - os povos da era ocidental - vale dizer, a característica de apreensão apenas do que se encontra fora do âmbito de sua intimidade, o que lhes era estranho ou propriamente o fogo do céu, fogo empedocliano que os fizeram sucumbir ao impulso sedutor do abismo. Para Hölderlin, os homens sempre apreendem melhor o que lhes são distante e estranho, mas com maior dificuldade o que lhes são próximo e íntimo. Numa carta a Böhlendorf de 4 de dezembro de 1801, cujo trecho mostramos a seguir, o poeta alemão indica o que seria doravante a tarefa dos poetas: compreender o que lhes é próprio e mais difícil, "apreender a medida, o sentido lúcido e também a firme subsistência nesse mundo". ${ }^{25}$

O autenticamente racional perde preponderância com o progresso da formação. Por isso, a maestria dos gregos no pathos sagrado era

24 BLANCHOT, Maurice. op.cit., p. 130.

25 BLANCHOT, Maurice. O espaço literário. Tradução: Álvaro Cabral. Rio de Janeiro: Rocco, 1987. p. 272. 
menor, pois o tinham inato; são excelentes, pelo contrário, no dom da representação desde Homero, pois este homem extraordinário tinha uma alma rica em alto grau a fim de apropriar-se da sobriedade juniana ocidental (...). Entre nós se sucede o inverso. Por isso é tão perigoso tomar as regras da arte extraindo-as exclusivamente da genialidade grega (...). O próprio deve ser apreendido tanto quanto o estranho (...). O trágico entre nós se resume em que nos encontramos totalmente silenciosos, em que, metidos em algum recipiente, distanciamo-nos do reino do vivo, em que devorados pelas chamas desejamos a chama que não podemos nos unir. ${ }^{26}$

Trata-se de reconhecer que os gregos, por natureza, já possuíam o "pathos sagrado" e resumiam em si o tormento do "fogo do céu" como inato e pulsante. Por isso, apreenderam melhor o que lhes era estranho, apreenderam a "sobriedade juniana ocidental", o racional, a claridade da representação e a lucidez conceitual notadamente expressos na genialidade de Homero. Segundo Hölderlin, ao contrário, os Hespérides são por natureza próximos da claridade e atravessados pela sobriedade racional, por isso apreenderam justamente o que, no caso deles, lhes eram estranho: responderam à exigência da palavra sagrada e ao apelo sedutor do abismo, tornando-se os senhores do "pathos sagrado" como conquista trágica, embora se distanciando do que era decisivamente característico em sua natureza: a "sobriedade juniana ocidental".

Gradativamente, o poeta alemão vai se distanciando daquele impulso de abandono no ilimitado garantido pelo Todo-presente e que se realiza no dilaceramento, em proveito de uma espécie de "retorno categórico" tal como Blanchot o denomina, retorno encarado como um convite feito por Hölderlin para a doravante tarefa trágica: assumir com todas as conseqüências o que é estranho aos Hespérides: a "firme subsistência nesse mundo". Os textos da maturidade de Hölderlin não são rompimentos definitivos com o período anterior, mas, a nosso ver, intensificação do próprio caráter trágico que deve se realizar no homem, um convite que Blanchot registrou da seguinte forma: "essa espécie de lei que Hölderlin formula aqui parece não ter ainda senão o alcance de um preceito limitado que convida os poetas do seu país, e que o convida a ele próprio, a não se abandonarem desmedidamente à vontade empedocliana, à vertigem e ao turbilhão do fogo". ${ }^{27} \mathrm{Em}$ outros termos, a intensificação do trágico nos textos da maturidade de Hölderlin se realiza no instante em que exige a tarefa de permanecer na terra, cujo retorno das profundezas do abismo deve se realizar através de uma 
separação ilimitada dos deuses, ou antes, pela compreensão da "noite do afastamento dos deuses" $:^{28}$ a infidelidade divina.

A oposição entre natureza e arte da juventude aparece agora como relação entre deus e o homem, expressa sob a forma de infidelidade. N'O espaço literário Blanchot utiliza os textos da maturidade de Hölderlin, sobretudo Observações sobre Édipo e Observações sobre Antígona, a fim de compreender a apresentação trágica em que os deuses se desviam.

Édipo é o melhor exemplo de como a arrogância do herói, a obstinação ilimitada e a desmesura podem lançar as sementes que doravante germinarão a fim de impulsionar o herói no infortúnio. O desejo impetuoso de onisciência em Édipo põe em curso um processo que vai lentamente escalando os degraus da queda do herói. Na análise de Hölderlin, Édipo é tomado por uma "suspeita irada" que o impulsiona a querer saber precisamente o que não pode suportar: "quando rompeu os limites (...), o saber se incita antes de tudo a saber mais do que pode suportar ou apreender" ${ }^{29}$ É interessante que a mesma arrogância é encontrada também nas Observações sobre Antígona, cuja heroína é arrebatada por um "espírito de selvageria" que se comporta com elevada insolência contra deus, indo "de encontro a ele com palavras audaciosas e muitas vezes até blasfematórias". ${ }^{30}$

Na medida em que Édipo se envereda nas tramas tortuosas de sua origem, envolve-se pouco a pouco numa malha que não mais conseguirá se desprender, no instante em que alcançar o máximo de consciência a respeito de sua gênese. Édipo inicia seu percurso de clarividência a todo custo ou de "inteligibilidade do todo" quando "interpreta de modo demasiadamente infinito a sentença do oráculo". Sua impetuosidade é desejo de unificação com deus, onisciência a qualquer preço que termina num movimento que se volta contra o próprio herói. Desde sua suspeita que se volta à procura do assassino de Laio: "Quem dentre vós souber por quem/ Pereceu o filho de Lábdaco, Laio, / Digo-lhe que me revele tudo, etc."; passando pela necessidade de querer interpretar também as palavras de Tirésias: "Mas ele será reconhecido, morando com seus filhos, / Como irmão e como pai, e da mulher que o gerou, / Filho e marido, em um mesmo leito com/ o pai e o seu assassino"; recusando o pedido de Jocasta que entrevê o infortúnio doloroso que estava prestes a cair dos céus em proveito da clarividência a todo custo de sua origem: "Pois Édipo inclina seu ânimo/ Para múltiplos tormentos, não interpreta, / Como um homem sensato, o novo a partir do antigo. (...) Pelos deuses, não! Se te preocupas com a vida, / Não procures. Já estou

\footnotetext{
SZONDI, Peter. op.cit., p. 36.

29 HÖLDERLIN, Friedrich. Observações sobre Édipo. Tradução: Pedro Süssekind (inédita). p. 4 (inédita).p. 10.

HÖLDERLIN, Friedrich. Observações sobre Antígona. Tradução: Pedro Süssekind
} 
bastante aflita"; até a enorme perplexidade e estupefação com que recebe angustiadamente a revelação do mensageiro, que diz tê-lo soltado os pés sem cumprir o pedido do velho Laio de o assassinar: "Como, pelos deuses, velho, fala alguma coisa!/ O que dizes? Pólibo não me semeou?/ Mensageiro - Praticamente tanto quanto um de nós"; em todo desenvolvimento "predomina nas falas principalmente a procura doentia de uma consciência". ${ }^{31}$

A interpretação demasiada infinita que força a unificação com deus, aprofundando a exigência de onisciência, termina por se voltar contra o herói: "É justamente essa busca de tudo, essa interpretação de tudo, que no final rebaixa seu espírito aquém da linguagem rude e simples dos seus criados". Trata-se de "consciência que suprime consciência", ${ }^{32}$ um processo de conclusão após conclusão que culmina na derradeira e mais terrível verdade: aquela contra o próprio herói. O resultado da impetuosidade edipiana de interpretar o oráculo de maneira demasiada infinita, com a posterior execução da sentença termina em ilimitada unificação com os deuses, quer dizer, trata-se de um impulso de fidelidade ilimitada que une numa Totalidade homem e deus.

No entanto, se a hybris que arrebata Édipo acaba forçando essa unificação, o efeito trágico de purificação desse acasalamento ilimitado, segundo Hölderlin, deverá ser doravante compreendido como impulso de separação ilimitada entre deus e o homem. A ira selvagem que unifica tem de ser purgada através do divórcio ou da separação ilimitada. Em outros termos, os deuses se desviam e revelam sua enorme infidelidade ao voltar as costas contra os homens: "A apresentação do trágico depende principalmente de que o formidável, como o deus e o homem se acasalam, e como, ilimitadamente, o poder da natureza e o mais íntimo do homem se unificam na ira, seja concebido pelo fato de que a unificação ilimitada se purifica por meio de uma separação ilimitada [grifo nosso]". ${ }^{33}$ Portanto, a unificação ilimitada se transforma em separação ilimitada a fim de que o "formidável" possa ser reconhecido.

Hölderlin intensifica a noção de trágico quando indica a infidelidade divina como efeito purgador daquele abandono do homem na Totalidade, ou purificação do sentimento ilimitado de abandono de si em proveito do "pathos sagrado". Homem e deus se comunicam através da infidelidade, visto ser ela a que melhor expressa essa relação. O terrível divórcio termina por purificar o sentimento arrebatador de hybris, mas ao mesmo tempo, arremessa o homem no estrangeiro, uma terra em que o dia é tomado por

31 HÖLDERLIN, Friedrich. Observações sobre Édipo. p. 5.

32 HÖLDERLIN, Friedrich. Observações sobre Antígona, p.12.

33 HÖLDERLIN, Friedrich. Observações sobre Édipo, p. 7. 
um eterno crepúsculo, uma noite em que todos os deuses se afastam: as "trevas da cegueira de Édipo". ${ }^{34}$

Blanchot menciona o desvio a propósito desse afastamento dos deuses; esse desvio é precisamente o processo de rompimento ou a infidelidade divina. Ao poeta trágico, doravante, resta cumprir e levar às últimas conseqüências esse afastamento dos deuses, sem que o espaço vazio deixado pelo crepúsculo dos celestiais seja preenchido com vãs consolações. $O$ poeta trágico, tal como o herói cujo formidável se apresenta tragicamente como separação ilimitada, é lançado na errância e no exílio, quer dizer, "exilado de deus e no erro, por eu ter confiado no delírio da irritação". ${ }^{35}$ Tornando-se o desencaminhado, esgota-se na andança cuja caminhada "é essa força árida que desenraiza a paisagem, devasta o deserto, estraga o lugar".

O convite de Hölderlin para que os poetas aprendam agora o que é mais difícil e que lhes está próximo é aceito através de um retorno à terra, desvio da vontade empedocliana e do pathos sagrado em proveito de um voltar-se em direção à terra; assumir a infidelidade divina e radicalizar o afastamento dos deuses experimentando a noite intranqüila que produz vertigem e tensão. Mais ou menos como numa antecipação profética da fórmula nietzscheana em que Zaratustra ensina aos homens a mais terrível das reversões: "Eu vos rogo, meus irmãos, permanecei fiéis à terra". ${ }^{36}$

A aceitação trágica da infidelidade divina é chamada por Blanchot de "retorno categórico". Digamos de início que não se trata da formulação apressada de nostalgia da terra natal, retorno a uma região primeva que não deixa de ser vestígios aspiradores do Todo-presente. Além disso, também não é simples negação típica de uma simplificação humanista, mas desprendimento da Totalidade oriundo do próprio abandono que os deuses realizam em relação aos homens. Para além da negação intransigente, o poeta reconhece - tal como Hölderlin pressentiu na sua época - um tempo em que os deuses se desviam e estão ausentes. Desviando-se dos homens os deuses se revelam infiéis, eles se afastam exigindo do homem o reconhecimento desse distanciamento, inclusive permanecendo e assumindo inexoravelmente essa infidelidade: "o homem deve compreender o sentido sagrado dessa infidelidade"; ${ }^{37}$ doravante, homem e deus entram em comunicação sob a forma de infidelidade, esquecimento de tudo e desvio dos deuses.

A exigência de retorno categórico confina o homem num sofrimento torturante. Sofrimento que consiste em não poder ser suportado, mesmo

34 SZONDI, Peter. op.cit., p. 36.

35 BLANCHOT, Maurice. A conversa infinita. Tradução: Aurélio Guerra Neto. São Paulo: Escuta, 2001. p. 65.

36 NIETZCHE, Friedrich. Assim falou Zaratustra. Prólogo, 3. Tradução: Mário da Silva. Rio de Janeiro: Bertrand Brasil, 1998.

37 BLANCHOT, Maurice. O espaço literário, p. 273. 
porque o sofrimento só é purificador se a ele não se consegue suportar, do contrário, não passa de palavrório de intelectual ocioso. Quando Hölderlin escreve, a propósito de Édipo, que a experiência do sofrimento extremo lança o homem nas únicas "condições do tempo ou do espaço", significa que resta a ele apenas a terra, a fidelidade à terra, mesmo que ela tenha se convertido numa região vertiginosa, revelando-se unicamente em silêncio e vazio. Ao retornar à terra, o poeta experimenta um tempo inoperante, um presente que não tem fim e é inesgotável, que não mais admite nenhuma consolação redentora e o força a viver exclusivamente tal qual a marcha desse presente ininterrupto: ele não pode mais se lançar num entorpecimento esperançoso de um futuro em que todas as coisas encontrarão um dia seu lugar correto. Nas Observações sobre Antígona Hölderlin registrou esse comportamento do tempo que o poeta, doravante fiel à terra, deverá experimentar: "mas isso sempre acontece quando o tempo é contado no sofrimento, porque então o ânimo segue a marcha do tempo com muito mais sentimento e concebe assim o curso simples das horas, mas sem que o entendimento conclua do presente para o futuro". ${ }^{38}$

Como se o poeta devesse experimentar na pele o peso do instante que não passa, a contagem dos segundos do relógio que se alongam ininterruptamente. Assumir a infidelidade divina é, também para Blanchot, experimentar esse tempo sem consolação, uma temporalidade como o outro do tempo. Fidelidade terrena que conduz o poeta ao extremo limite do sofrimento, em que "o tempo está como que parado (...), o tempo como outro (...) que precisamente não pode mais nos libertar, não constitui um recurso, tempo sem acontecimento, sem projeto, sem possibilidade, perpetuamente instável": "o presente do sofrimento é o abismo do presente". ${ }^{39}$ Este sofrimento prolongado sem cessar significa que, ao poeta, restam apenas as condições da fidelidade à terra; experiência limite de uma dor que não tem pressa e que, "nesse limite", escreve Hölderlin, "o homem esquece de si, porque está inteiramente no momento; o deus, porque é apenas tempo; e ambos são infiéis". ${ }^{40}$ Nessa separação ilimitada o poeta realiza a experiência de estranheza, experiência nômade de retorno categórico, mas que, paradoxalmente, não pode mais permanecer numa morada porque "simplesmente não pode se igualar ao que era no início".

Aqui podemos entender melhor como Hölderlin intensifica sua compreensão do trágico quando escreve sobre a infidelidade divina, ou, como quer Blanchot, quando os deuses se desviam. Convidando a renunciar ao abandono no pathos sagrado, Hölderlin fala de um deus mais autêntico

38 HÖLDERLIN, Friedrich. Observações sobre Antígona, p. 11.

39 BLANCHOT, Maurice. A conversa infinita, p. 88s.

40 HÖLDERLIN, Friedrich. Observações sobre Édipo, p. 7. 
que, ao se desviar, interrompendo a ligação desse mundo com o "mundo selvagem dos mortos", força também o homem a abandonar aquele mundo a fim de permanecer numa região em que só lhe resta ser fiel e, ao mesmo tempo, reconhecer a infidelidade divina. Esse convite é que torna o trágico mais intensificado. Permanecer no infundado é fidelidade à terra ao invés da vontade empedocliana, experiência de separação ilimitada. Vale a pena registrarmos uma anotação de Blanchot muito refinada a propósito disso:

Tarefa mais próxima dos objetivos do homem, tais como se nos impõem hoje, mas mais trágica do que a prometida a Empédocles e a que assegurava aos gregos a união com os deuses. Hoje, o poeta não pode mais colocar-se entre os deuses e os homens, como intermediário deles, mas cumpre-lhe manter-se entre a dupla infidelidade, manter-se na interseção desse duplo retorno divino, humano, duplo e recíproco, movimento pelo qual se abre um hiato, um vazio que deve constituir doravante a relação essencial dos dois mundos. Assim, o poeta deve resistir à aspiração dos deuses que desaparecem e que o atraem para eles em seu desaparecimento; deve resistir à pura e simples subsistência na terra, aquela que os poetas não fundam; deve realizar a dupla inversão, tomar a seu cargo o peso da dupla infidelidade e manter assim distintas as duas esferas, vivendo puramente a separação, sendo a vida pura da própria separação, pois esse lugar vazio e puro que distingue esferas, é aí que está o sagrado, a intimidade da dilaceração que é o sagrado. ${ }^{41}$

A separação ilimitada que purga o excesso forçando o homem à terra, coloca-o num eterno entretempo; por um lado, abandona a morada redentora do fogo empedocliano e, por outro lado, o mantém fiel numa temporalidade em que o tempo se perde no sofrimento, num presente que não passa; trata-se de uma zona intermediária entre a vizinhança do fogo e a fronteira do sofrimento sem pressa, espaço que o poeta deve conservar puro e vazio. A antecipação da fórmula "permanecei fiéis à terra" de Zaratustra, coincide também com outro ensinamento nietzscheano. Tal como o poeta que se volta à terra e deve permanecer na ausência e no afastamento dos deuses, Nietzsche ensina o grande amor e a grande afirmação: "amor fati, seja este, doravante, o meu amor!”. ${ }^{42}$ Manter-se na ausência de Deus, preservando e radicalizando o desvio dos deuses como amor à terra e ao destino. $O$ eterno andarilho que vive em zonas intermediárias, mais ou me-

$41 \quad$ BLANCHOT, Maurice. O espaço literário, p. 275.

42 NIETZSCHE, Friedrich. A gaia ciência. Aforismo, 276. Tradução: Paulo César de Souza. São Paulo: Companhia das Letras, 2001. 
nos como o dionisíaco dizer-sim ao mundo de Nietzsche, afirmação sem desconto e exceção que experimenta a existência da maneira mais trágica: "Minha fórmula para isso", escreve Nietzsche, "é amor fati". ${ }^{33}$

O entendimento de Hölderlin do trágico em que o formidável se apresenta numa purificação da união ilimitada através da separação ilimitada, desvio dos deuses ou infidelidade divina, convida, portanto, ao tempo e ao espaço. Assumir uma dupla tortura: o sopro gelado de um tempo vazio seguido por um cortejo de desamparo, e a dor que não cessa no homem por ter que permanecer à terra, cuja comunicação com os deuses se expressa através da infidelidade. O mistério da noite do distanciamento dos deuses é isso: da cegueira de Édipo exilado dos deuses até o desvio divino que consiste num virar as costas ao poeta, a infidelidade é torturante ao mesmo tempo em que torna o herói ou o poeta ainda mais trágico.

Quando escreve sobre a infidelidade divina, Hölderlin já estava muito próximo da loucura que, para ele, foram regiões fronteiriça, torturante e dolorosa; regiões muito próximas ao estrangeiro, à experiência de estranheza que o conduziu lentamente a se perder num solo que se fendia a todo instante. Para usarmos a formulação de Blanchot, Hölderlin foi arrebatado pelo Fora absoluto, espaço sem intimidade nem repouso. Em todo caso, o herói trágico de Hölderlin se faz reconhecer também nas reflexões de Blanchot sobre o poeta trágico. Ambos são seduzidos ou pela Totalidade do pathos sagrado ou pela fidelidade incondicional à terra; seduzidos pelo impulso ao abismo ou pela Circe da infidelidade divina.

43 NIETZSCHE, Friedrich, Obras incompletas. In: Os Pensadores. Tradução: Rubens Rodrigues Torres Filho. São Paulo: Nova Cultural, 1999. p. 445. 


\title{
RESUMO
}

O objetivo desse texto é relacionar Blanchot e Hölderlin através do percurso de dois momentos do itinerário poético de Hölderlin: por um lado, os textos da juventude em que o poeta anseia por um sentimento de unidade ou conciliação entre natureza e arte, cuja unidade deve se realizar no personagem trágico, realização conciliatória que ocorre de forma trágica numa espécie de impulso ao abismo - impulso à morte -; e, por outro lado, a noção de infidelidade divina que aparece na maturidade de Hölderlin a propósito da apresentação do trágico, quer dizer, uma espécie de impulso que resta ao homem apenas fidelidade à terra depois que o poeta experimenta a "noite do afastamento dos deuses". O percurso do artigo é norteado pelas reflexões de Blanchot a partir de dois textos em que ele trata de modo mais sistemático a questão do trágico: "A palavra 'sagrada' de Hölderlin", publicado em $A$ parte do fogo e "O itinerário de Hölderlin" que aparece em $O$ espaço literário, textos em que, respectivamente, abordam os dois momentos distintos de Hölderlin. Assim, essa relação indica que o herói trágico de Hölderlin se faz reconhecer também nas reflexões de Blanchot sobre o poeta e sua existência trágica. Ambos são seduzidos ou pela Totalidade do "pathos sagrado" ou pela fidelidade incondicional à terra; seduzidos pelo impulso ao abismo ou pela Circe da infidelidade divina.

Palavras-chave: Trágico; impulso ao abismo; infidelidade divina.

\begin{abstract}
The aim of this article is to connect Blanchot and Hölderlin with two moments of Hölderlin's poetical itinerary: on the one hand, the texts from his youth, in which the poet seeks a feeling of unity or conciliation between nature and art that must occur within the tragic character, a conciliatory achievement that takes place in a tragic way in a kind of impulse to abyss impulse to death -; on the other hand, the texts from his maturity, in which the notion of divine infidelity comes up in relation to the presentation of the tragic, that is, a kind of impulse that remains only as fidelity to the earth after man experiences "the night of parting from the gods". The organization of this article follows some of Blanchot's ideas exposed in two texts in which he deals with the tragic in a systematic way: "Hölderlin's 'holy' word", published in The Work of Fire and "Hölderlin's itinerary", included in The Space
\end{abstract}


of Literature; these two texts deal with both of Hölderlin's moments, respectively. In this way, Hölderlin's tragic hero makes himself known also in Blanchot's analyses of the poet and of his tragic existence. Both the poet and the tragic hero are seduced either by the Totality of "holy pathos" or by an unconditional fidelity to the earth; they are seduced by an impulse to abyss or by Circe's divine infidelity.

Key-words: Tragic; impulse to abyss; divine infidelity.

\section{REFERÊNCIAS}

BLANCHOT, Maurice. A parte do fogo. Tradução: Ana Maria Scherer. Rio de Janeiro: Rocco, 1997.

. O espaço literário. Tradução: Álvaro Cabral. Rio de Janeiro: Rocco, 1987.

. A conversa infinita. Tradução: Aurélio Guerra Neto. São Paulo: Escuta, 2001.

DELEUZE, Gilles. Crítica e clínica. Tradução: Peter P. Pelbart. São Paulo: Ed. 34, 1997.

GÁBAS, Rául. El todo-uno del idealismo alemán em la poesia de Hölderlin. In: Enrahonar, 32/33, p. 43-65, 2001.

HÖLDERLIN, Friedrich. Hypérion. Tradução: Márcia Sá Cavalcanti Schuback. Petrópolis: Vozes, 1993.

. Observações sobre Édipo. Tradução: Pedro Süssekind (inédita).

. Observações sobre Antígona. Tradução: Pedro Süssekind (inédita).

NIETZSCHE, Friedrich. A gaia ciência. Tradução: Paulo César de Souza. São Paulo: Companhia das Letras, 2001. 1998.

. Assim falou Zaratustra. Tradução: Mário da Silva. Rio de Janeiro: Bertrand Brasil,

. Obras incompletas. In: Os Pensadores. Tradução: Rubens Rodrigues Torres Filho. São Paulo: Nova Cultural, 1999.

SZONDI, Peter. Ensaio sobre o trágico. Tradução: Pedro Süssekind. Rio de Janeiro: Jorge Zahar, 2004. 